\title{
How might a Stoic eat in accordance with nature and "environmental facts"?
}

\author{
Kai Whiting \\ William O. Stephens \\ Edward Simpson \\ Leonidas Konstantakos
}

This is a post-peer-review, pre-copyedit version of an article published in Journal of Agricultural and Environmental Ethics. The final authenticated version is available online at DOI: 10.1007/s10806-020-09829-w 


\title{
How Might a Stoic Eat in Accordance with Nature and "Environmental Facts"?
}

\begin{abstract}
This paper explores how to deliberate about food choices from a Stoic perspective informed by the value of environmental sustainability. This perspective is reconstructed from both ancient and contemporary sources of Stoic philosophy. An account of what the Stoic goal of "living in agreement with nature" would amount to in dietary practice is presented. Given ecological facts about food production, an argument is made that Stoic virtue made manifest as wisdom, justice, courage, and temperance compel Stoic practitioners to select locally sourced, low resource input, plant-based foods whenever circumstances allow.
\end{abstract}

Keywords: diet; Stoicism; sustainability; veganism; vegetarianism; virtue ethics

\section{Introduction}

Economic development has reduced financial poverty and improved the quality of life for many of the world's inhabitants, but it has also created environmental imbalances and socioeconomic injustices. Humanity is encroaching on planetary boundaries, most notably biosphere integrity and biogeochemical flows, with agriculture, forestry and fishing representing the three primary factors influencing Earth's delicate balance (Haberl et al., 2007; Rockström et al., 2009; Steffen et al., 2015; Swartz et al., 2010). The effect of societal activities has been quantified via various measures in the form of biodiversity and carbon, material and water footprints (George, 1988). These metrics enable us to quantify depletion of resources and show that we are exhausting the Earth at a speed quicker than the planet can regenerate (Blomqvist et al., 2013; Wackernagel et al., 2004; Wackernagel and Rees, 1998).

The foods we choose to buy have huge impacts, for better or worse, on our societies and the biosphere. Diet is a personal and sometimes a religious or political statement, as the Roman statesman and Stoic Seneca the Younger testifies:

I began to abstain from animal foods, and a year later the habit was both easy and pleasant for me. I thought my mind was livelier, and even today I suspect it might have been. Would you like to know why I gave it up? The time when I was a young man was in the early years of Tiberius's principate. Religions of foreign origin were then being eliminated, and abstinence from animal foods was considered proof of adherence. So at the request of my father (who did not fear opprobrium but had a hatred of philosophy), I returned to my former habits Letters to Lucilius 108.22, translated by Graver and Long (2015).

Thus, our food choices can, and often do, express our social status, our preferences, and our moral judgements. Mindful eating can thus strengthen social bonds, build communities, and forge our identities. Food can also be a means of distinguishing ourselves from others, by identifying as a vegan, for example (Greenebaum, 2012). This is particularly true for wealthier individuals who enjoy great flexibility in their food choices. Indeed, there is 
evidence of an increasing tendency for citizens of wealthier nations to gravitate towards vegetarianism and veganism (Vegan Society, 2019).

This paper explores the role of food and diet in ancient and contemporary Stoicism and its impact on the world. Many factors pertaining to Stoic food ethics could have been considered: fair trade, labour practices, religious rituals, personal health, and the ethical treatment of animals. However, we focus on how certain dietary choices promote or hinder environmental sustainability and thus restrict our scope to evaluate meat and fish production and consumption. Our point of departure is the ancient Stoic call to "live according to Nature". This expression was the ancient Stoics' definition of the human telos (goal). Consequently, we argue that how and what a Stoic practitioner chooses to eat necessarily affects the perfection of her agency and reflects her progress in the four chief Stoic virtues of wisdom, temperance, courage, and justice. That said, we stop short of discussing the epistemological considerations of ethical decisions about food. Rather, we begin with the premise that Stoics seek to follow "environmental facts" precisely because in doing so they can live happy, flourishing lives.

\section{Key Stoic Concepts}

Zeno of Citium founded the philosophy of Stoicism at around 300 BCE in Athens. The works of Zeno and other early Hellenistic Stoics survive only in fragments, but substantial writings of the Roman Stoics Seneca the Younger, Musonius Rufus, Epictetus (via his student Arrian), and Marcus Aurelius are extant. Unsurprisingly, the elements of Stoic philosophy developed in the Roman period constitute the bulk of what is now considered the Stoic "canon".

The $21^{\text {st }}$ century has seen the rise of a modern form of Stoicism with growing numbers of enthusiasts organising and attending conferences and engaging in group activities (LeBon, 2018). Books, blogs, academic material, and the number of authors exploring Stoic philosophy have proliferated, particularly in the self-help space (e.g. Holiday and Hanselman, 2016; Irvine, 2008; Robertson, 2013, 2010). Other researchers have discussed contemporary societal challenges to Stoics (Konstantakos, 2014; Stephens, 2018a; Whiting et al., 2018a). This movement thus reflects the ongoing development of, re-engagement with, and reinterpretation of ancient Stoic principles by contemporary thinkers committed to achieving the daily practice of the four Stoic virtues of courage, justice, self-control, and wisdom needed to live well (Gill, 2014; Lopez, 2018).

For Stoic practitioners, the best way to live one's life is to deliberately perfect one's rational agency. This requires focusing on that which is under one's control, namely, one's own thoughts, judgements, choices, and actions. The perfection of reason is virtue. The latter is a unitary mental state that encompasses one's intentions, decisions and attitudes. When facing dangers in pursuit of noble causes, this mental state is called courage. When determining what is deserved or fair it is called justice. When regulating appetites for food, drink, money and sexual pleasures, virtue is called temperance or self-control. When judging what is good, bad, or neither, virtue is called wisdom. For Stoics, then, virtue is "a form of knowledge that shapes their whole personality and life" (Gill, 2014).

A key tenet of Stoicism is that virtue is the only true good and is alone both sufficient and necessary for happiness precisely because a neurotypical human being is in complete control 
of working towards virtue. Consequently, in contrast to things like health, material possessions, pleasure, reputation, political power, and social status, virtue brings about selfrealisation and enduring fulfilment (Gill, 2014; Stephens, 1994a). All things that are neither virtues (which are morally good) nor vices (their opposites, which are morally evil) are regarded by Stoics as neither good nor bad, but "indifferents" or "externals". These are subdivided into "preferred indifferents" or "dispreferred indifferents". To view the possession or absence of an external as indifferent to one's fulfilment does not mean that a Stoic would disregard or ignore it. Rather, it means that possessing or lacking an "external" need not have an impact on one's moral character, and so as such has no bearing on one's capacity to flourish. In other words, one can be wealthy yet morally bankrupt. One can be physically weak but morally strong. Likewise, someone can be healthy and wealthy yet utterly miserable. Conversely, one could be poor and sick, yet content in knowing that her present circumstances neither define the kind of person she is, nor prevent her from achieving eudaimonic wellbeing. The latter refers to a more holistic conception of human thriving. Eudaimonia is a Greek term that roughly refers to a person's ability to flourish, i.e. lead a "life well-lived." Consequently, under a Stoic virtue ethics and eudaimonic framework, what matters is not whether a person has or lacks wealth or health, but rather how appropriately she uses her wealth or poverty, health or illness (Whiting et al., 2018b). It follows that the way one pursues externals and obtains them (or manages without them) reflects one's progress towards virtue, and thus it is the pursuit that governs one's happiness or misery.

Accordingly, neither eating nor going hungry makes a person good or bad, virtuous or vicious. Rather, Stoics regard the decisions one makes about eating and hunger as virtuous or vicious, temperate or gluttonous, just or unjust. Food choices are, however, important considerations for a Stoic practitioner's daily routine as Stephens (2018b) explains:

While the Stoics held that food in itself contributes nothing to a person's happiness, how one obtains, prepares, and serves it, and both what and how one eats, all reveal a person's character as good or bad. Thus, understanding the purpose of food, the necessity of frugality, and the virtue of temperance are all important in Stoicism.

\section{Stoicism, food and diet}

Exploring how a contemporary Stoic might eat, if not subject to physical and economic constraints, is not a trivial philosophical exercise. Rather, it is a legitimate concern with serious, daily implications for a growing community of practitioners, called as they are "to live according to Nature."

It is necessary, though challenging, to build a coherent contemporary Stoic framework that takes into consideration environmental ethics because the facts we face in the $21^{\text {st }}$ century differ vastly from the world lived in by the ancient Stoics. For one thing, environmental facts unequivocally demonstrate the role human diet has on maintaining the planet's temperature below the safe threshold of a $1.5 \mathrm{C}$ average increase (IPCC, 2018). Through contemporary scientific and philosophical enquiry (e.g. Gjerris et al., 2011) we now also better understand the characteristics of the animals we exploit. These facts clearly indicate that Epictetus and Chrysippus were mistaken in their assertion that the sole purpose of a nonhuman animal's 
existence is to be used by human beings (see Nussbaum, 2006; Sorabji, 1993). In some respects, this understandable misjudgement, given the rudimentary science of the ancient period, is partly corrected by Whiting et al's addition of the "environment" to the Stoic "circles of concern". The latter is a conceptual model originally conceived by the Stoic Hierocles to illustrate individuals' relationships and responsibilities to themself and others. By extension, it also provides the conceptual basis for the practice of virtuous acts that flow from the self. This basis is not rooted exclusively in scientific fact, but also rests upon the Stoic value claim that Nature is central to human wellbeing. Consequently, the anthropocentric view that Earth exists to benefit humankind only makes sense if humans operate in harmony with the universe as a whole.

By including it in the circles of concern, the "environment" becomes formally acknowledged as something deserving consideration in and of itself. As a result, one can easily demonstrate the virtue of recognising that an animal, plant, or ecosystem has its own nature, one that is independent of human experience. In other words, Epictetus' and Chrysippus' error does not nullify the usefulness of Stoicism in addressing issues pertaining to environmental ethics precisely because it is a fundamentally Stoic principle to apply the virtue of justice towards animals, plants, and the planet at large. This understanding is not a modern interpretation, as it aligns with Zeno's call to live according to Nature and the Stoic understanding that humans flourish only when individuals use their privileged position, as rational and moral agents, to harmonise with the Whole.

A second complication arises when examining how a Stoic is to ascertain which diet(s) are most likely to cause the least damage to the environment. Even if one could show that vegetarianism is the best response to anthropogenic climate change or to mitigating the harms of intensive farming practices that make it impossible for animals to live according to their natures, Stoicism and vegetarianism are two separate philosophies (Corter, 2018; Pigliucci, 2018).

An ethical vegetarian may argue that when avoidable, the use of animal products, including meat, is vicious or unreasonable because of the harms caused to the environment, to a subset of animals, or to human health (Deckers, 2009; Stephens, 1994b). A Stoic, on the other hand, views material harms as indifferent externals, that is to say, neither morally good nor bad in and of themselves. Instead, it is the motive and intention bringing about that harm that Stoics evaluate as virtuous or vicious. Consequently, the crux of the decision centres on whether a Stoic is obligated to change her diet given her circumstances. How does virtue inform how she thinks about food production and agricultural resources? What does virtue dictate she judge about food waste, scarcity, and world hunger? What does virtue commend her to choose for meals? And how does virtue prompt her to act regarding food and sustainability?

Operating within a Stoic framework means that there are no invariable, universal prescriptions regarding dietary choices, i.e. that a Stoic practitioner must abstain from a certain food regardless of circumstances. Rather, a person would abstain from a specific type of food or drink if doing so constituted an appropriate act or intention. This then requires Stoics to ascertain (directly or indirectly) whether their choices are in line with the philosophy's call to think and act with courage, justice, temperance, and wisdom. 
This kind of decision making explains why Seneca (in Letters to Lucilius, 33.11) emphasised that the earlier Stoic philosophers were not our masters but our guides. It is therefore worth asking whether knowledge of environmental facts and commitment to Stoic ethics ought to lead contemporary Stoics to think and act differently about food than the ancient Stoics, who did not have such facts available to them.

\subsection{Ancient Stoic Texts}

Seneca the Younger (in Letters 8.5, 95.15-18 and 119.13-14) explains that progress towards virtue requires limiting our wants to our basic needs. In terms of food, he describes natural desire as that which asks for nothing beyond the removal of hunger and feeling satisfied. $\mathrm{He}$ contrasts human nature with the nature of "beasts" when he criticises overeating as vicious. Before he turned to Stoicism, Seneca was interested in the philosophy of Pythagoras. Pythagoreans abstained from meat, which allowed Seneca's teacher Quintus Sextius to argue that "a person could get enough to eat without resorting to butchery; and that when bloodshed is adapted to the purposes of pleasure, one develops a habit of cruelty" (Letter 108.17). His teacher also reasoned that abstaining from animal food products does not harm anyone and even if the above arguments were false, then vegetarianism remains more economical. Persuaded by these arguments, Seneca adopted vegetarianism. He remarks that his meat-free diet was easy, pleasant, and that it helped him think better. At the time, however, vegetarianism was associated with foreign religions and so it was considered threatening to conservative Romans like Seneca's father. Thus, Seneca the Elder asked his son to give up his vegetarianism. Out of filial piety, Seneca the Younger obediently complied (Letters to Lucilius, 108.22). Yet it is worth noting that Seneca the Stoic never denied the cogency of the arguments for a vegetarian diet. Although he returned to occasionally eating meat, he continued to insist upon the frugality of simple, inexpensive foods that were easy to obtain and simple to prepare.

Seneca's younger contemporary, Gaius Musonius Rufus, contended (in Lectures 18A) that progress towards the virtue of temperance required controlling what one eats and drinks, thus making him perhaps the most emphatic Stoic advocate of vegetarianism ${ }^{1}$. His appeal to live in accord with Nature when it came to eating was based on the view that the stomach was made for the same purpose as the root of a plant - to obtain nutrients, not to stimulate pleasure (Lectures 18B). Musonius also taught that one should prefer that which is simple to prepare and that which is abundant over that which is scarce and complicated to prepare. Like Seneca, his frugal diet ruled out exotic, expensive delicacies imported from distant lands. Yet, he went further than most Roman Stoics in asserting that meat is "unsuitable" for human beings:

Just as one should choose inexpensive food over expensive food, and food that is easy to obtain over food that is hard to obtain, one should choose food suitable for a human being over food that isn't. And what is suitable for us is food from things which the earth produces: the various grains and other plants can nourish a human being quite well. Also nourishing is

\footnotetext{
${ }^{1}$ Since a much smaller portion of Musonius' original texts survive, caution is required when judging his views. This caution includes his views on food ethics.
} 
food from domestic animals which we don't slaughter. The most suitable of these foods, though, are the ones we can eat without cooking: fruits in season, certain vegetables, milk, cheese, and honeycombs. These foods also are easiest to obtain. Even those foods that require cooking, including grains and some vegetables, are not unsuitable; all are proper food for a human being (Lectures 18A.2, as translated by King, 2010, 71).

In addition to judging meat to be too crude and heavy for human consumption, Musonius agreed with Seneca that meat muddles the mind:

He argued that a meat-based diet was too crude for humans and more suitable for wild beasts. He said that it was too heavy and that it impeded mental activity. The fumes which come from it, he said, are too smoky and darken the soul. For this reason, those who eat lots of meat seem slow-witted (Lectures 18A.3, as translated by King, 2010, 71).

While a contemporary Stoic can dispel Musonius' unscientific claims, Musonius clearly believed that cooking and eating meat harms the soul, impedes the mind, and damages one's moral character. Like Seneca, he criticises embellishing food to amuse one's greedy yet finicky palate (Lectures 18A.4). Musonius argues that opulent food harms our bodies (Lectures 18A.5) and reports that Zeno of Citium likewise rejected delicacies:

Zeno thought it best to avoid gourmet food, and he was adamant about this. He thought that someone who once experiences gourmet cuisine would want it all the time, inasmuch as the pleasure associated with drinking and eating creates in us a desire for more food and drink (Lectures 18A.6, as translated by King, 2010, 72).

Musonius' student Epictetus followed earlier Stoics in conceiving of Nature as providential. In Discourses (1.9.8-9) he remarks on the "ignorance" of people worried about food by contrasting it with the observation that wild animals are self-sufficient because they are adapted to, and in harmony with, Nature (Discourses, 1.9.8-9). From this perspective, Epictetus asserts that "god created some beasts to be eaten, some to be used in farming, some to supply us with cheese, and so on" (Discourses, 1.6.18). He endorses abstinence from delicacies for reasons of temperance and frugality (e.g. Discourses 3.13.21 and 3.24.37-38), not out of concern for any animal's wellbeing.

Epictetus' view echoes that of the early Stoic theorist Chrysippus, who argued that things "were created for the sake of human beings and gods... so that human beings can make use of beasts for their own purposes without injuring (or doing wrong) to them (sine iniuria)" (Cicero, On Ends 3.67, Long and Sedley 1987, 57 F(5)).

Stoic anthropocentrism is also glaring in Chrysippus' alleged remark that life had been given to the pig as a form of salt to keep it from going rotten and to preserve it for human use (Long and Sedley 1987, 54 P; Cicero, On the Nature of the Gods 2. 154-62, esp. 160; Sedley 2009, pp. 231-38).

While we oppose the scientifically misinformed basis for anthropocentrism declared in these texts from Chrysippus and Epictetus quoted above, two other comments by Epictetus are salutary and provide practical insights to contemporary Stoics that we shall return to later on: 
Those who have truly digested their philosophical principles show it by eating, drinking, dressing, marrying, having children, and being citizens, as a human being should (Discourses 3.21.1-5).

What decides whether a sum of money is good? The money is not going to tell you; it must be the faculty that makes use of such impressions - reason. (Discourses 1.1.5)

The first text affirms that one's observable daily practices reveal one's actual philosophical commitments. The relevant habit here, in other words, is that eating is believing. The second text can also apply to eating. The food on a plate is not going to tell us whether it is goodonly reason can do that. Reason, in turn, requires some understanding of the underlying processes of food production and their impacts, which could be obtained through the reading of peer evaluated scientific methods and analysis (e.g. Baroni et al., 2007).

In his private journal, which later became Meditations, the Roman emperor Marcus Aurelius comments little on food. Yet he often reminds himself to see all the things that unthinking people commonly covet for what they are really are. His message: there is no point in getting excited about dead meat because wisdom matters much more than cuisine. In this example, on his dinner table lie a dead fish, a dead bird, a dead pig:

"That's what we need to do all the time-all through our lives when things lay claim to our trust - to lay them bare and see how pointless they are, to strip away the legend that encrusts them (Meditations, vi. 13, as translated by Hays, 2003, 71).

In conclusion, both Marcus Aurelius and Epictetus (in Discourses 1.1.5 and 3.21.1-5) offer poignant commentaries on how a Stoic practitioner's understanding of food and dietary choices either advance her toward virtue or drag her into vice. Musonius Rufus and Seneca concur that eating luxurious, extravagant and decadent foods stimulates fussiness and selfindulgence, and so must be rejected. Both of these Roman Stoics explicitly endorse vegetarian habits to promote temperance, simplicity, and health.

\subsection{Eating According to Nature}

For ancient Stoics the meaning of "live according to Nature" was sufficiently clear with only minor points being contested over the period. It was a call to align oneself with the benevolent and rational will of a pantheistic notion of god, in recognition of the divine essence of the perfect reason (logos) and breath (pneuma) which pervade god's body. Mindful consideration of animals and plants, as limbs of god's body, manifests virtue (Protopapadakis, 2012). Virtue, the ultimate good, is beneficial for its own sake, for our sake, and for the sake of the universal community (Boeri, 2009).

Contemporary Stoics who believe that the universe is a rational organism are often referred to as "traditional Stoics". When deciding upon a virtuous course of action, traditional Stoics appeal to Nature's providential care (see Cicero, On the Nature of the Gods 2.83, 100-1, 122-30, Long and Sedley 1987, 54J) and our privileged role within that reality as intelligent animals capable of thinking and acting rationally. 
Those who have perfected their reason have learned how to live in complete harmony with the cosmic order pervaded by logos. These people have attained infallible judgement and wisdom and are called sages. To strive to live in harmony with Nature is to pursue this ideal of sagehood as the only path that leads to human flourishing. Therefore, one's propensity to engage in "virtuous" or "vicious" behaviour is revealed in one's interactions with other living beings and the wider world. This understanding of reality provides the ethos of the Stoic cosmopolitan ideal, as depicted in the Stoic "circles of concern". The latter is a metaphor which displays our moral obligations towards our "self", our "family", our "friends", our local "community", "all humanity" and the "environment". The responsibility of taking care of each member is represented by a concentric circle. It does not rest on the presumption that any human, non-human animal, plant, rock, species, or ecosystem has intrinsic value, but rather derives from the Stoic-based recognition that we are each obligated as a limb of god's body (or as a rational element of the universe) to play our part in taking care of others and thereby to promote the proper functioning of the Whole.

For contemporary Stoic philosophers who are sceptical of the notion of a divine or a providentially ordered universe (e.g. Becker (2017), Pigliucci (2017) and Stankiewicz (2017)) the answers to practical questions like "what should a Stoic eat?" are not derived from any theological belief about the universe. Instead they are obtained from Becker's secular call to "follow the facts", a principle which he believes should ground Stoic virtue ethics and moral agency:

Following nature means following the facts. It means getting the facts about the physical and social world we inhabit and the facts about our situation in it - our own powers, relationships, limitations, possibilities, motives and intentions and endeavours - before we deliberate on normative matters. It means facing those facts-accepting them for exactly what they are, no more, no less... it means doing ethics from the facts. (Becker, 2017, p 46)

Thus, when Pigliucci (2018) explains his reasoning behind Stoics following a vegetarian diet, he does so by stating, with reference to Discourses 1.1 .5 , that it is reason that informs our ethics and that scientific-based reason should redirect the way we think about what is right and what is wrong when it comes to eating habits [because] reason-given contemporary scientific knowledge - very much tells us that we, as Stoics, ought to be vegetarians.

Pigliucci cites statistics on the number of livestock killed in the U.S. and questions whether the Earth could support mass meat consumption without disastrous damage to the natural environment. He also considers the sentience of those animals that are slaughtered, the moral urgency of grappling with animal ethics and our carbon footprint. In other words, he follows Becker's framework according to which to ignore our obligations, as informed by the facts, fundamentally undermines our agency and our progress towards eudaimonia.

According to the Beckerian position, what a neurotypical human being ought to do can be derived from facts about human values, preferences, historical events, cultural norms and social conventions (Becker, 2017). These facts do not derive from what traditional Stoics refer to when they speak of "living according to Nature", a prescription that affirms the goodness inherent in the laws of nature. Instead, for Modern Stoics "virtue" is not an 
objective intrinsic property of nature but arises extrinsically from human subjectivity, thought, and action.

The problem is that the wanton environmental devastation typical of much of humanity's interaction with Earth over the last 250 years results directly from the values embedded in, and our commitment to, the present socioeconomic system. Another challenge modern Stoics face with their secularised position is that living according to non-moral facts seems to run afoul of Hume's infamous fact-value distinction (Hume, 2006). For traditional Stoics this issue is circumvented by their logocentric framework and their belief that the universe is intrinsically good, that it provides normative purpose, and that it is the source of both moral and non-moral facts. In this respect, the call to "live according to Nature", far from being outdated or archaic, offers rich insights that enable us to re-think our relationship with Earth and all its inhabitants. An in depth discussion of the nuances of the traditional (orthodox) and Beckerian (heterodox) Stoic theological positions and their environmental consequences is beyond the scope of this paper, but is provided by Whiting and Konstantakos (2019). Here it suffices to say that for both Stoic camps facts are objective and beyond our control, but how we interpret them and how we choose to act in light of them is up to us.

Our best scientific understanding does not always secure the luxury of incontestable facts. Sometimes we must resort to projections based on the best available data. The conclusions reached from such models are approximations which may be inaccurate or, worse, correct but misunderstood, misinterpreted, or flatly denied for political gain. This can have and has had grave consequences for the natural world, which appears to be far more complex than we can fully understand and does not thrive when reduced to purely utilitarian nomenclature that labels it a resource for human commodification and exploitation (e.g. the term "fish stock", rather than "fish population").

In this respect, facts rooted in a unified cosmic framework can be a helpful means of highlighting the flaws in a reductive, anthropocentric commodification of the natural world (Long, 2018). Where Lawrence Becker succeeds is in in clarifying the value of science and the pursuit of empirical facts in the modern context, knowledge which all contemporary Stoics can use to make decisions about a virtuous course of action. Hence, contemporary Stoics would do well to strive to live according to both facts and Nature, the latter being the holistic framework in which those facts are interpreted, and subsequent decisions are made.

\section{Eating Habits and their Environmental Effects}

What we choose to put on our plates is often a very personal, and/or a politically charged, decision. Our palates have been shaped by customs, cultural practices, family traditions, the habits of our friends, our levels of physical activity, and personal likes and dislikes of various foods. These dietary preferences are constrained by our incomes, taste buds, allergies, and health concerns. In industrialised societies the availability of food products involves complex production and distribution systems, as well as disposal mechanisms for both edible and inedible food waste. All these components of food supply and disposal chains have huge effects on human beings far and near, on domesticated and wild animals, on plant 
communities, and on the stability of our terrestrial and marine ecosystems. Due to the expansive nature of the subject at hand, we restrict our factual analysis here to the principal activities linked to large scale meat and fish production, i.e. the commercial breeding and raising of livestock and the commercial capture of wild fish and aquaculture.

\subsection{Agricultural Production}

Agriculture claims 50 percent of habitable land surface. However, when the amount of land devoted to pasture and to crops raised and converted to animal feed are factored in, 77 percent of agricultural land is either directly or indirectly devoted to animal husbandry, and only 23 percent to crops grown directly for human consumption (Ritchie, 2017). Agriculture linked to livestock also affects wildlife with 30 percent of the land now claimed by farm animals once home to wild animals (Steinfeld et al., 2006). Wildlife loss is of particular concern given that, according to the World Wildlife Fund's Living Planet Index, the populations of mammals, birds, reptiles, amphibians and fish fell by half in the last 40 years (WWF, 2014).

Vegetarians and vegans are often criticised for contributing to the destruction of ecologically sensitive areas by substituting animal products with soybeans. However, this criticism is misguided. Whilst it is true that inappropriately planted soy crops will cause such problems, the vast majority of the soya crop is destined for livestock/fish feed and not for vegetarians and vegans. In fact, according to the United States Department of Agriculture (USDA, 2015, p. 1):

Just over 70 percent of the soybeans grown in the United States are used for animal feed, with poultry being the number one livestock sector consuming soybeans, followed by hogs, dairy, beef and aquaculture.

To produce crops for animal feed is an inefficient way to produce food for human consumption, regardless of how efficiently we try to raise farm animals. This is because of the loss of calories that occurs along the food chain (van Zanten et al., 2016). Indeed, the transformation of plants into animal flesh destroys about 90 percent of the calories, since not all plant-derived nutrients are converted into what human beings would consider edible food product. In other words, more people could be supported from the same amount of land if they followed a vegetarian diet (Godfray et al., 2010). In fact, if the food industry replaced animal-based items in the American diet with plant-based alternatives 350 million more people could be fed (Shepon et al., 2018).

One can of course argue that if one raises animals on grassland unsuitable for arable farming, then the efficiency of food productivity increases. This idea holds some merit. However, this does not rectify the problem of shrinking habitats for wildlife species which could otherwise re-colonise some of these areas. A Stoic would also consider a number of other factors relative to other available food options, before advocating for the eating of meat produced in such regions. These include but are not limited to: (a) the amount of energy and freshwater required to produce the food; (b) the ecological costs of the fuel/electricity required to produce the food; (c) the air, land and water pollution generated; (d) the distance and the difficulty with which the food was transported from its source(s) to the plate; (f) social and 
health factors that lie beyond the scope of this paper but would invoke considerations into labour conditions, the comparative nutritional value of the food and the scientific consensus about the health risks of habitually eating the food etc.

With respect to climate change, the agricultural sector is responsible for 25 to 33 percent of greenhouse gas emissions, half of which is caused by livestock (Edenhofer, 2015; Gerber et al., 2013; Steinfeld et al., 2006; Tubiello et al., 2014). Most of these emissions originate from animal feed production and the form in which ruminants digest their food (Berners-Lee et al., 2012; Harwatt et al., 2017; Herrero et al., 2016; Westhoek et al., 2014). Grazing systems, for example, produce only 13 percent of the cattle meat and 6 percent of the cattle milk produced by the food industry but generate approximately 20 percent of all emissions assigned to livestock, upon factoring in land use change-related impacts (Garnett et al., 2017; Gerber et al., 2013).

Water is another major factor in the impact of agriculture on the environment. Agricultural use accounts for 69 percent of freshwater withdrawals (FAO, 2016; Molden, 2013). Much more water is needed to generate animal products than crops of equivalent nutritional value. For example, in their study of the EU-28 countries, Vanham et al. (2013) show that the category "animal products" is responsible for 45 percent of all freshwater consumed. Arable farming is the second highest consumer at 37 percent, yet these products provide more calories. Likewise, (Mekonnen and Hoekstra, 2012) show that at $10 \mathrm{~L} / \mathrm{kcal}$ the average water footprint per calorie of beef is 20 times that of cereals and starchy roots, whilst the water footprint per gram of protein derived from milk, eggs or chicken meat, at $30 \mathrm{~L} / \mathrm{g}$ protein, is 1.5 times larger than that of pulses. This huge gulf in nutritional value between plant and animal food sources, relative to the volume of water each consumes, has led the leading expert of water footprints to call for national and international policies that restrict the growth of the meat and dairy industry (Hoekstra, 2014, 2013).

\subsection{Wild Fishing and Aquaculture Food Production}

Marine animals currently constitute a substantial component of the human diet in most countries. According to the FAO (2018), total fish production in 2016 reached a record high of 171 million tonnes, 88 percent of which was diverted to direct human consumption. The per capita consumption was likewise a record high of $20.3 \mathrm{~kg}$. Furthermore, these species are often overlooked in discussions of sustainability and food ethics. However, if we consider that 17 percent of the animal protein consumed by the global population originates from fish (FAO, 2018), we must scrutinise the methods used in removing marine creatures from their habitat and the operations of fish farms. Furthermore, if everyone were to switch from meat to fish, many environmental problems would be exacerbated.

\subsubsection{Sea Catch}

Deep sea fishing is subsidised at great cost to the environment and fish populations, especially when we consider that fleets operating in the deep seas are not profitable. In fact, in the $21^{\text {st }}$ century fishing vessel expeditions tend to be insensitive to both declines in fish population and economic downturns, as they are often propped up by market policies and cultural protectionist mechanisms (Kroodsma et al., 2018). Other explanations supported by 
extensive data collection highlight the existence of nefarious working practices, including illegal fishing boats and underreporting of the catch. In fact, an estimated 20 to 32 percent of wild-caught seafood imported into the US is obtained from uncertain, illegal and unreported sources of origin (Pramod et al., 2014). This prevents proper measures from being put in place to safeguard vulnerable marine species (Sala et al., 2018).

The environmental footprint of commercial deep sea fishing is much larger than those of other forms of food production, even though fish capture (as opposed to aquaculture) provides only 1.2 percent of global calorific production for human food consumption (Kroodsma et al., 2018). More alarming is the speed at which marine populations have declined - a registered 10 percent level of overfishing in 1974 compared to 66.9 percent in 2015 (FAO, 2018).

The WWF (2015) voices similar concerns, identifying a 50 percent reduction in marine population numbers globally between 1970 and 2010. This is due to unsustainable fishing practices and habitat degradation linked to climate change and human encroachment. Destruction of coral ecosystems is particularly significant because while reefs only account for 0.1 percent of the ocean's surface area - which is half the area of France - reefs support 25 percent of all marine species (Cinner et al., 2016; Pratchett et al., 2018; Spalding et al., 2001). Commercial fishing is also implicated in harmful greenhouse gas emissions. Trawlers, for example, are responsible not only for the mass destruction of the marine ecosystem but also have a higher carbon footprint per kcal than poultry and dairy farms (Clark and Tilman, 2017; Hall-Spencer et al., 2002). To reduce their environmental impact some people have turned to commercial aquaculture initiatives, but are these options any better?

\subsection{Fish Farming}

In 2016, 80 million tonnes of fish were farmed for food consumption. This represents 47 percent of all the non-terrestrial meat produced for human consumption (FAO, 2018). Given the predicted world population in 2050 aquaculture and regional food insecurity that is likely to be exacerbated by climate change, aquaculture if responsibly developed and practised, can make a significant contribution to global food security and economic growth (Mathiesen, 2014). It can also, if done properly, prevent the conservation challenges presented in the previous section.

The environmental impact of fish farming, as with other forms of food production, depends greatly on how each site is operated. In terms of climate change, aquaculture facilities in lakes, rivers and fjords have a smaller carbon footprint than their counterparts using tanks, but they are still on a par per kcal with poultry and dairy farms (Clark and Tilman, 2017). Other problems facing aquaculture include eutrophication, and the introduction of antibiotics and other wastes that pollute the environment. However, such issues can be more easily avoided with better planning (Herath and Satoh, 2015). Likewise, the judicious placement of such farms can avoid harm to mangroves, wild fish nurseries and other delicate ecosystems that are affected by reduced local water quality (Asche et al., 2016). Similarly, thoughtfully adapting operations to allow for the co-habiting of natural predators can prevent environmental conflicts like, for example, culling seals to prevent them from eating farmed 
fish. That said, it is an environmental concern when wild caught fish are used to feed farmed fish. There are other issues linked to animal ethics such as fish farm overcrowding, sea lice and the associated impacts that both have on farmed and wild fish population health and wellbeing. However, these dimensions are beyond the scope of this present paper and relate more to whether a given food choice raises specific animal ethics concerns rather than whether it is sustainable from a purely environmental point of view.

\section{A Stoic diet for living in accordance with Nature and environmental facts}

From a Stoic perspective, only a fool eats out of ignorance, apathy, laziness or blind habit. A person who eats heedless of the environmental facts presented in the previous sections is not progressing towards virtue because she is ignoring how and the extent of which, her dietary decisions affect environmental justice. She is also failing to seek wisdom. By acting mindlessly or complacently following the latest fad she is failing to exercise self-control. In some cases, especially if she is succumbing to peer pressure, she may also lack the courage to do what is right. In all these cases, such a person is behaving in a way that is contrary to virtue, contrary to reason, and so contrary to Nature.

Eating in agreement with Nature and "environmental facts" requires approaching all of one's food choices mindful of justice, moderation, courage, and ecological wisdom. For Stoics, living in agreement with Nature means living in agreement with reason. The perfection of reason is virtue. Stoics believe that virtue is a single, unified disposition of the mind. This mental disposition discerns what is good, what is bad, and what is neither good nor bad. Thus, this mental disposition is also known as wisdom. Stoics understand the wisdom of being connected to Earth and its processes of growth and renewal. 'Ecology' literally means the rational account or rational principle (logos) of home (oikos). Thus, living in agreement with Nature calls for embracing the embeddedness and interconnectedness of human beings with all other species of animals and plants that coinhabit our ecological communities, that is to say, share our "home".

So does wisdom dictate that a Stoic ought to be a vegan, lacto-vegetarian, ovo-vegetarian, occasional pescatarian or flexitarian? It depends on circumstances, the availability and affordability of alternatives, one's nutritional needs, allergies, interpersonal relationships, and societal role. One's reasons and motives at play in deliberating about food will always be guided by a conception of how living in agreement with Nature informs virtuous choices for every Stoic according to his or her present situation and circumstances. So, for example, when would a Stoic eat fish? Consider the case of a community of Stoic Pacific islanders or Stoic visitors to those islands. The geographic location of these small, remote lands are often hundreds or even thousands of miles from mainland farms that produce ample amounts of grains, legumes, vegetables, and nuts. The terrain and the soils of these islands also make growing of such crops near-impossible. In which case, the artisanal practice of small-scale fishing for sustenance and cultural reasons would be preferable to importing non-native foods by plane and ship, which aside from being impractical involves considerable fuel consumption and greenhouse gas emissions. 
As with artisanal small-scale fishing, Stoics particularly admire small-scale farming and gardening when done with wisdom and care. The connection to nature that comes with investing in healthy, sustainable food production that harmonises with Earth's systems leads Roman Stoics like Musonius Rufus to extol the virtues of farmers:

The earth repays most beautifully and justly those who care for her, giving back many times what she receives... Only someone decadent or soft would say that agricultural tasks are shameful or unsuitable for a good man... To me, this is the main benefit of all agricultural tasks: they provide abundant leisure for the soul to do some deep thinking and to reflect on the nature of education - Musonius Rufus, Discourses Lecture 11, 1-3 (as translated by King, 2010).

Stoics believe that human beings are social animals. Accordingly, communal gardening and considerate farming practices offer practitioners the opportunity to engage with others in a way that promotes kinship ties, equity and fair dealing, which in turn represents an opportunity to work towards the virtue of justice (Long and Sedley, 1987: 380). In addition to the communal benefits of gardening and farming, a Stoic will also affirm ethically savvy shopping, meal preparation, cooking and dining with companions. This is because all these food-related activities strengthen social bonds and fortify friendships.

As we have seen, Stoic wisdom dictates frugality and simplicity in eating and drinking. It also requires moderation or self-control. In terms of food consumption, it is a particularly Stoic practice to scrutinise and reflect upon one's thoughts and actions that have occurred throughout the day. In turn, this involves closely examining one's desires, values and beliefs, as these will trigger impressions that will drive one's choices and actions. Many preferences for food, at least for those who rarely reflect on them, are learned, conditioned, and culturally habituated. Consequently, those who claim that they would die if they gave up meat, whether they are being sincere or hyperbolic, are grounding their dietary habits in the tyranny of gustatory desire rather than the sober consideration of facts. Other times they might fallaciously be "appealing to nature", by claiming that is "natural" to eat meat and therefore desirable. Neither position is grounded in Stoic ethics or theology (which holds that nature is inherently good, not that if something is natural then it is good, see Whiting and Konstantakos, 2019). Instead, a sound Stoic practice emphasises the virtue of self-control, thereby empowering a person to rule her desires and not be ruled by them.

In the ancient texts, Stoics offer various examples about curbing one's desire either because food is unavailable or so extravagant that it conflicts with wisdom or moderation. Epictetus, for example, says that if you desire a fig or a bunch of grapes in the winter when they are out of season, you are a fool (Discourses 3.24.86). As we have seen in Section 3.1, for Musonius Rufus, food choices that conflict with Nature are often characterised by finicky, fussy, or neurotic habits.

When applying ancient Stoic teaching to specific dietary choices, it not difficult to see that extravagant, expensive foods that require lots of energy to produce, or travel many miles from source to plate, would be rejected as ecologically unsustainable and foolish. Likewise, foods produced by inflicting tremendous suffering on non-human animals can easily be 
rejected as unnecessarily cruel, unjust, and unsustainable. Wasting agricultural resources so that the privileged can indulge in meat and dairy products while millions suffer from food insecurity, poor health and the environmental consequences associated with these diets typify what Stoics regard as the vices of gluttony and greed.

One can also apply Stoicism to very specific food choices. Take for instance the frequent consumption of fast food. As most fast foods tend to be highly processed, high in animal fats, high in sodium, high in sugar, and so comparatively unhealthy, they clash with "living according to Nature" (Schlosser, 2012). A more appropriate "Stoic" diet will take into consideration the slow and gradual growth cycle of plants, sustainable methods of growing crops, and gentle harvesting methods. Food preparation also matters, so a Stoic will value the deliberate, frugal, simple preparation of wholesome meals. Consequently, a Stoic will prefer to avoid fast and processed food.

Is organic food desirable for a Stoic? This will depend. Stoics are not swayed by trends. They are prudent eaters, not fussy fad-followers. If an organic food product is affordable, accessible, nutritionally superior, and ecologically more sustainable than its non-organic counterpart, then a Stoic will opt for it.

What about the virtue of courage? Consider "carnism", defined as an ideology that holds that it is normal, natural, and necessary to eat meat (Joy, 2011). For vegans and vegetarians in a carnist society, it can take courage to talk about food ethics, food injustice, and the manifold harms of the meat and dairy industrial complex (Joy, 2011, pp. 149-150). It is understandable that people may take it personally when their food habits and dietary preferences are scrutinised. It is even more understandable that they take offense when their food choices are criticised on ethical grounds. But working for environmental justice is the right thing to do and this requires scrutinising dietary choices.

Doing the right thing in the face of powerful, often threatening, resistance is a decent definition of courage. Thus, a Stoic committed to eating in agreement with Nature will strive to eat courageously and will encourage others to do so as well. That said, a Stoic on a plantbased diet would use discretion and candour at social occasions where the dishes on offer contain meat, dairy products, or eggs. A Stoic would be discrete and honest when discussing carnism with habitual meat-eaters. She might not initiate the discussion intent upon "proving a point", but rather would embrace an opportunity to share wisdom about how living according to Nature led her to think and act courageously, temperately, and justly in her dayto-day activities, including her eating and drinking.

In short, it takes discipline to change one's eating habits. A Stoic dedicated to cultivating the virtue of moderation will strive to eat in a manner which treads lightly on the planet. Selfcontrol obviously prohibits eating more calories than one needs for healthy activity. It also steers a Stoic away from foods that require disproportionately large inputs of energy and other resources to produce, package, transport, and cook. On a global scale, the kinds of foods that consume the most energy and resources are meat and dairy products extracted from intensively raised animals. Therefore, at the very least, Stoics should eat smaller quantities of animal products, be willing to pay more for them, and not waste them. Stoics should take the 
time to find out where these products come from and the conditions in which the animals that provided them were raised. Likewise, if Stoics are going to eat sea food, they should observe and support aquaculture farming practices that clean the environment (e.g. Baker et al., 2015). They should be wary of fishing practices that reduce marine biodiversity, damage marine ecosystems, and reduce populations of marine organisms to the point that the species cannot recover its genetic fitness. Such practices disrespect Nature, harm marine organisms, and disrupt the stability and integrity of marine ecosystems.

So, given the facts, if a Stoic sincerely desires to live virtuously and in accord with Nature, then she will acknowledge that a vegan diet will significantly reduce her impact on the planet. That said, Stoicism does not prescribe personal choices in a rule-based fashion, so it is not the case that a Stoic must always, regardless of circumstance, opt for a meat-free diet. We have argued that contemporary Stoics should generally opt for vegetarian, or vegan, locally sourced, low-input, plant-based foods over plant-based foods that require greater resources to produce or that require greater energy to transport. Where and when a plant-based diet is impossible, Stoics should take extra care to buy meat from local farms that meet the high standard of humanely raised certification (e.g. that of the Animal Welfare Institute).

That said, it would not be Stoic to rigidly rank diets from best to worst. So, the question should not be whether there is one perfectly virtuous Stoic diet for everyone everywhere. There isn't. Stoics don't pretend to be saints. Nor are Stoics dreamy idealists. Stoics must simply practice their Stoicism. So, instead of making explicit judgements, regardless of context, the types of questions a Stoic should be asking include: how can I work with others to promote sustainable practices, justice, conserve biodiversity, support animal welfare, reduce waste, and reduce GHGs, while making wise, frugal, and circumspect choices about my own eating patterns?

\section{References}

Asche, F., Roheim, C.A., Smith, M.D., 2016. Trade intervention: Not a silver bullet to address environmental externalities in global aquaculture. Mar. Policy 69, 194-201.

Baker, S., Grogan, K., Larkin, S., Sturmer, L., 2015. "Green" Clams: Estimating the Value of Environmental Benefits (Ecosystems Services) Generated by the Hard Clam Aquaculture Industry in Florida. University of Florida, Gainesville, FL, USA.

Baroni, L., Cenci, L., Tettamanti, M., Berati, M., 2007. Evaluating the environmental impact of various dietary patterns combined with different food production systems. Eur. J. Clin. Nutr. $61,279$.

Becker, L.C., 2017. A new stoicism: revised edition. Princeton University Press, Princeton, New Jersey.

Berners-Lee, M., Hoolohan, C., Cammack, H., Hewitt, C.N., 2012. The relative greenhouse gas impacts of realistic dietary choices. Energy Policy 43, 184-190.

Blomqvist, L., Brook, B.W., Ellis, E.C., Kareiva, P.M., Nordhaus, T., Shellenberger, M., 2013. Does the shoe fit? Real versus imagined ecological footprints. PLoS Biol. 11, e1001700.

Cinner, J.E., Pratchett, M.S., Graham, N.A.J., Messmer, V., Fuentes, M.M.P.B., Ainsworth, T., Ban, N., Bay, L.K., Blythe, J., Dissard, D., 2016. A framework for understanding climate change impacts on coral reef social-ecological systems. Reg. Environ. Change 16, 1133-1146. 
Clark, M., Tilman, D., 2017. Comparative analysis of environmental impacts of agricultural production systems, agricultural input efficiency, and food choice. Environ. Res. Lett. 12, 064016.

Corter, J., 2018. On Vegetarianism and Stoicism [WWW Document]. Mod. Stoicism. URL https://modernstoicism.com/on-vegetarianism-and-stoicism-by-jeremy-corter/ (accessed 12.7.18).

Deckers, J., 2009. Vegetarianism, sentimental or ethical? J. Agric. Environ. Ethics 22, 573.

Edenhofer, O., 2015. Climate change 2014: mitigation of climate change. Cambridge University Press.

FAO, 2018. The State of World Fisheries and Aquaculture 2018: Meeting the sustainable development goals. Food and Agriculture Organization of the United Nations, Rome, Italy.

FAO, 2016. AQUASTAT: Water uses [WWW Document]. URL http://www.fao.org/nr/water/aquastat/water_use/index.stm

Garnett, T., Godde, C., Muller, A., Röös, E., Smith, P., De Boer, I.J.M., zu Ermgassen, E., Herrero, M., Van Middelaar, C.E., Schader, C., 2017. Grazed and confused?: Ruminating on cattle, grazing systems, methane, nitrous oxide, the soil carbon sequestration question-and what it all means for greenhouse gas emissions. Food Climate Research Network, University of Oxford, Oxford, UK.

George, K.P., 1988. Biodiversity and biotechnology. J. Agric. Ethics 1, 175-192.

Gerber, P.J., Steinfeld, H., Henderson, B., Mottet, A., Opio, C., Dijkman, J., Falcucci, A., Tempio, G., 2013. Tackling climate change through livestock: a global assessment of emissions and mitigation opportunities. Food and Agriculture Organization of the United Nations (FAO), Rome, Italy.

Gill, C., 2014. What is Stoic Virtue?, in: Ussher, P. (Ed.), Stoicism Today: Selected Writings. Stoicism Today Project.

Gill, C., n.d. The Stoics on humans, animals and nature (unpublished).

Gjerris, M., Gamborg, C., Röcklinsberg, H., Anthony, R., 2011. The price of responsibility: ethics of animal husbandry in a time of climate change. J. Agric. Environ. Ethics 24, 331-350.

Godfray, H.C.J., Beddington, J.R., Crute, I.R., Haddad, L., Lawrence, D., Muir, J.F., Pretty, J., Robinson, S., Thomas, S.M., Toulmin, C., 2010. Food security: the challenge of feeding 9 billion people. science $327,812-818$.

Graver, M., Long, A.A., 2015. Seneca. Letters on Ethics: To Lucilius. The University of Chicago Press, Chicago \& London.

Greenebaum, J., 2012. Veganism, identity and the quest for authenticity. Food Cult. Soc. 15, 129144.

Haberl, H., Erb, K.-H., Krausmann, F., Gaube, V., Bondeau, A., Plutzar, C., Gingrich, S., Lucht, W., Fischer-Kowalski, M., 2007. Quantifying and mapping the human appropriation of net primary production in earth's terrestrial ecosystems. Proc. Natl. Acad. Sci. 104, 1294212947.

Hall-Spencer, J., Allain, V., Fosså, J.H., 2002. Trawling damage to Northeast Atlantic ancient coral reefs. Proc. R. Soc. Lond. B Biol. Sci. 269, 507-511.

Harwatt, H., Sabaté, J., Eshel, G., Soret, S., Ripple, W., 2017. Substituting beans for beef as a contribution toward US climate change targets. Clim. Change 143, 261-270.

Hays, G., 2003. The Meditations of Marcus Aurelius. The Modern Library, New York, US.

Herath, S.S., Satoh, S., 2015. Environmental impact of phosphorus and nitrogen from aquaculture, in: Feed and Feeding Practices in Aquaculture. Elsevier, pp. 369-386.

Herrero, M., Henderson, B., Havlík, P., Thornton, P.K., Conant, R.T., Smith, P., Wirsenius, S., Hristov, A.N., Gerber, P., Gill, M., 2016. Greenhouse gas mitigation potentials in the livestock sector. Nat. Clim. Change 6, 452.

Hoekstra, A.Y., 2014. Water for animal products: a blind spot in water policy. Environ. Res. Lett. 9, 091003.

Hoekstra, A.Y., 2013. The water footprint of modern consumer society. Routledge.

Holiday, R., Hanselman, S., 2016. The Daily Stoic: 366 Meditations on Wisdom, Perseverance, and the Art of Living. Penguin. 
Hume, D., 2006. An enquiry concerning the principles of morals. Oxford University Press, Oxford, UK.

IPCC, 2018. Summary for Policymakers, in: Global Warming of $1.5^{\circ} \mathrm{C}$. An IPCC Special Report on the Impacts. Intergovernmental Panel on Climate Change, Geneva, Switzerland.

Irvine, W.B., 2008. A guide to the good life: The ancient art of stoic joy. Oxford University Press. Joy, M., 2011. Why we love dogs, eat pigs, and wear cows: An introduction to carnism. Conari Press, San Francisco, CA, USA.

King, C., 2010. Musonius Rufus: Lectures and Sayings. Lulu Press, Morrisville, NC, USA.

Konstantakos, L., 2014. Would a Stoic Save the Elephants?, in: Ussher, P. (Ed.), Stoicism Today: Selected Writings. Stoicism Today Project.

Kroodsma, D.A., Mayorga, J., Hochberg, T., Miller, N.A., Boerder, K., Ferretti, F., Wilson, A., Bergman, B., White, T.D., Block, B.A., 2018. Tracking the global footprint of fisheries. Science 359, 904-908.

LeBon, T., 2018. 6 years of stoic weeks: have we learnt so far?

Long, A.A., 2018. Stoicisms Ancient and Modern [WWW Document]. Mod. Stoicism. URL https://modernstoicism.com/stoicisms-ancient-and-modern-by-tony-a-a-long/ (accessed 12.7.18).

Long, A.A., Sedley, D.N., 1987. The Hellenistic Philosophers: Volume 1, Translations of the Principal Sources with Philosophical Commentary. Cambridge University Press, Cambridge, UK.

Lopez, G., 2018. Stoic Fellowship - Current Members 8th November 2018. Personal Correspondence. Mathiesen, Á.M., 2014. Fish farms to produce nearly two thirds of global food fish supply by 2030 [WWW Document]. URL http://www.fao.org/news/story/en/item/213522/icode/ (accessed 7.1.19).

Mekonnen, M.M., Hoekstra, A.Y., 2012. A global assessment of the water footprint of farm animal products. Ecosystems 15, 401-415.

Molden, D., 2013. Water for food water for life: A comprehensive assessment of water management in agriculture. Routledge.

Nussbaum, M.C., 2006. The moral status of animals. Chron. High. Educ. 52, B6-8.

Pigliucci, M., 2018. Should a Modern Stoic be Vegetarian? [WWW Document]. Mod. Stoicism. URL https://modernstoicism.com/should-a-modern-stoic-be-vegetarian-by-massimo-pigliucci/ (accessed 12.7.18).

Pigliucci, M., 2017. How to Be a Stoic: Using Ancient Philosophy to Live a Modern Life. Hachette UK.

Pramod, G., Nakamura, K., Pitcher, T.J., Delagran, L., 2014. Estimates of illegal and unreported fish in seafood imports to the USA. Mar. Policy 48, 102-113.

Pratchett, M.S., Thompson, C.A., Hoey, A.S., Cowman, P.F., Wilson, S.K., 2018. Effects of coral bleaching and coral loss on the structure and function of reef fish assemblages, in: Coral Bleaching. Springer, pp. 265-293.

Protopapadakis, E., 2012. The Stoic Notion of Cosmic Sympathy in Contemporary Environmental Ethics. Antiq. Mod. World Recept. Anc. Cult. Serbian Soc. Anc. Stud. Belgrade 290-305.

Ritchie, H., 2017. How much of the world's land would we need in order to feed the global population with the average diet of a given country? [WWW Document]. Our World Data. URL https://ourworldindata.org/agricultural-land-by-global-diets (accessed 9.28.19).

Robertson, D., 2013. Stoicism and the Art of Happiness-Ancient tips for modern challenges: Teach Yourself. Hachette UK.

Robertson, D., 2010. The philosophy of cognitive-behavioural therapy (CBT): Stoic philosophy as rational and cognitive psychotherapy. Karnac Books.

Rockström, J., Steffen, W., Noone, K., Persson, Å., Chapin III, F.S., Lambin, E., Lenton, T.M., Scheffer, M., Folke, C., Schellnhuber, H.J., 2009. Planetary boundaries: exploring the safe operating space for humanity. Ecol. Soc. 14.

Sala, E., Mayorga, J., Costello, C., Kroodsma, D., Palomares, M.L., Pauly, D., Sumaila, U.R., Zeller, D., 2018. The economics of fishing the high seas. Sci. Adv. 4, eaat2504.

Schlosser, E., 2012. Fast food nation: The dark side of the all-American meal. Houghton Mifflin Harcourt, Boston, US. 
Shepon, A., Eshel, G., Noor, E., Milo, R., 2018. The opportunity cost of animal based diets exceeds all food losses. Proc. Natl. Acad. Sci. 115, 3804-3809.

Sorabji, R., 1993. Animal minds and human morals: The origins of the western debate. Duckworth, London, UK.

Spalding, M., Spalding, M.D., Ravilious, C., Green, E.P., 2001. World atlas of coral reefs. University of California Press, Berkeley, CA, USA.

Stankiewicz, P., 2017. Interview with Piotr Stankiewicz [WWW Document]. Mod. Stoicism. URL https://modernstoicism.com/interview-with-piotr-stankiewicz/ (accessed 12.7.18).

Steffen, W., Richardson, K., Rockström, J., Cornell, S.E., Fetzer, I., Bennett, E.M., Biggs, R., Carpenter, S.R., de Vries, W., de Wit, C.A., 2015. Planetary boundaries: Guiding human development on a changing planet. Science 347, 1259855.

Steinfeld, H., Gerber, P., Wassenaar, T.D., Castel, V., Rosales, M., Rosales, M., de Haan, C., 2006. Livestock's long shadow: environmental issues and options. Food \& Agriculture Organisation, Rome, Italy.

Stephens, W.O., 2018a. Refugees, Exiles, and Stoic Cosmopolitanism. J. Relig. Soc. Supplement 16, 73-91.

Stephens, W.O., 2018b. Stoicism and Food, in: Kaplan, D. (Ed.), Encyclopedia of Food and Agricultural Ethics. Springer, Dordrecht.

Stephens, W.O., 1994a. Stoic Naturalism, Rationalism, and Ecology. Environ. Ethics 16, $275-286$.

Stephens, W.O., 1994b. Five arguments for vegetarianism. Philos. Contemp. World 1, 25-39.

Swartz, W., Sala, E., Tracey, S., Watson, R., Pauly, D., 2010. The spatial expansion and ecological footprint of fisheries (1950 to present). PloS One 5, e15143.

Tubiello, F.N., Salvatore, M., Cóndor Golec, R.D., Ferrara, A., Rossi, S., Biancalani, R., Federici, S., Jacobs, H., Flammini, A., 2014. Agriculture, forestry and other land use emissions by sources and removals by sinks. Statistics Division, Food and Agriculture Organization, Rome, Italy.

USDA, 2015. USDA Coexistence Fact Sheets: Soybeans. United States Department of Agriculture, Washington, DC.

van Zanten, H.H., Mollenhorst, H., Klootwijk, C.W., van Middelaar, C.E., de Boer, I.J., 2016. Global food supply: land use efficiency of livestock systems. Int. J. Life Cycle Assess. 21, 747-758.

Vanham, D., Mekonnen, M.M., Hoekstra, A.Y., 2013. The water footprint of the EU for different diets. Ecol. Indic. 32, 1-8.

Vegan Society, 2019. Statistics [WWW Document]. Vegan Soc. URL https://www.vegansociety.com/news/media/statistics (accessed 7.1.19).

Wackernagel, M., Monfreda, C., Schulz, N.B., Erb, K.-H., Haberl, H., Krausmann, F., 2004. Calculating national and global ecological footprint time series: resolving conceptual challenges. Land Use Policy 21, 271-278.

Wackernagel, M., Rees, W., 1998. Our ecological footprint: reducing human impact on the earth. New Society Publishers.

Westhoek, H., Lesschen, J.P., Rood, T., Wagner, S., De Marco, A., Murphy-Bokern, D., Leip, A., van Grinsven, H., Sutton, M.A., Oenema, O., 2014. Food choices, health and environment: Effects of cutting Europe's meat and dairy intake. Glob. Environ. Change 26, 196-205.

Whiting, K., Konstantakos, L., 2019. Stoic Theology: Revealing or Redundant? Religions 10, 193.

Whiting, K., Konstantakos, L., Carrasco, A., Carmona, L.G., 2018a. Sustainable Development, Wellbeing and Material Consumption: A Stoic Perspective. Sustainability 10, 474.

Whiting, K., Konstantakos, L., Misiaszek, G., Simpson, E., Carmona, L., 2018b. Education for the Sustainable Global Citizen: What Can We Learn from Stoic Philosophy and Freirean Environmental Pedagogies? Educ. Sci. 8, 204.

WWF, 2014. Living planet report 2014: species and spaces, people and places. WWF International, Gland, Switzerland. 